2008

\title{
Investment Provisions in Economic Partnership Agreements
}

Gus Van Harten

Osgoode Hall Law School of York University, gvanharten@osgoode.yorku.ca

Follow this and additional works at: http://digitalcommons.osgoode.yorku.ca/reports

Part of the International Trade Law Commons

\section{Repository Citation}

Van Harten, Gus, "Investment Provisions in Economic Partnership Agreements" (2008). Commissioned Reports and Studies. Paper 130. http:// digitalcommons.osgoode.yorku.ca/reports/130

This Article is brought to you for free and open access by the Faculty Scholarship at Osgoode Digital Commons. It has been accepted for inclusion in Commissioned Reports and Studies by an authorized administrator of Osgoode Digital Commons. 


\title{
Investment Provisions in Economic Partnership Agreements
}

\author{
Gus Van Harten ${ }^{1}$ \\ March 2008
}

\section{SUMMARY}

The African, Caribbean and Pacific (ACP) group of countries are negotiating trade agreements with the European Union in six regional blocs. In December 2007, the CARIFORUM region was the first region to conclude a full 'Economic Partnership Agreement' with Europe. The Agreement includes provisions on trade in goods, services and investment, intellectual property, competition, and government procurement. This report examines the investment provisions of the CARIFORUM Economic Partnership Agreement as an illustration of the EPA model.

Key findings of the report are:

- The CARIFORUM Agreement requires the Parties to remove restrictions on foreign ownership of their economy in sectors where they undertake positive commitments to liberalize. It prohibits a variety of instruments that are commonly used to limit or screen foreign investment with a view to enhancing its benefits for the host economy. It also establishes an obligation of national treatment which is likely to preclude performance requirements that encourage economic linkages or protect domestic enterprises.

- The EPA model, represented by the Agreement, appears not to account for the potentially adverse impacts of foreign investment on development and regional integration or acknowledge the role of government in preventing and limiting these

${ }^{1}$ LLB, MES, PhD; Assistant Professor, Osgoode Hall Law School of York University, Toronto, Canada; author of Investment Treaty Arbitration and Public Law (Oxford University Press, 2007). Oxfam International is acknowledged as the funding source for this report. The views in this report are those of the author and do not necessarily reflect the views of Oxfam International. 
impacts. It sidelines domestic tools that can be used to encourage foreign investment, thus displacing the greater flexibility and adaptability that domestic instruments offer.

- The Agreement establishes an obligation of most-favoured-nation treatment which could be read expansively to incorporate into the Agreement post-establishment obligations from other investment treaties, including access to investor-state arbitration.

- By combining provisions on services and investment, the Agreement expands upon market access commitments in other trade agreements by including non-service (i.e. investment) sectors, and raises the prospect of future claims by foreign investors in service and non-service sectors alike.

- Although the Agreement does not contain an investor-state mechanism, its market access commitments will trigger post-establishment protections, including access to investor-state arbitration, that are available to European investors in other investment treaties. This exposes CARIFORUM states to major liabilities arising from the prospect of direct claims by investors and damages awards against the state. Such claims may arise in any sector with substantial foreign ownership and are particularly prevalent in the energy and resource sectors and in privatized sectors.

\section{Key recommendations are:}

- In their consideration of a proposed EPA, ACP states should consider their position not only in terms of costs and benefits of their market access commitments in sectors covered by an EPA, but also in terms of their post-establishment commitments under other investment treaties. They may wish to link EPA negotiations to the renegotiation or clarified interpretation of existing bilateral investment treaties with European states.

- The Agreement's definition of the right to regulate, and its exclusion of a commitment to privatize public undertakings, should be strengthened. The Agreement should also clarify that MFN treatment is limited to the pre-establishment phase of an investment. The commitment in the Agreement to liberalize the capital account should be subject to the balance of payments safeguard.

- The Agreement should preclude the arbitration under other investment treaties of disputes concerning the rights and obligations of the Parties to the Agreement, or of disputes that are the subject to dispute settlement under the Agreement. Negotiations towards an EPA also offer an opportunity to provide for investor claims arising under existing BITs between an EC state and a CARIFORUM state to be referred to the CARIFORUM dispute settlement process instead of BIT arbitration.

- ACP states should avoid any further commitments to investor-state arbitration in an EPA or in any other treaty. Future consents to investor-state arbitration should be limited to investment contracts that are concluded in anticipation of a specific project. 


\section{Investment-related provisions in the CARIFORUM EPA}

The Parties to the CARIFORUM Agreement are the CARIFORUM states, acting collectively, and the 'EC Party', which includes both the European Community and its Member States, to the extent that the competence of each is implicated. ${ }^{2}$ This is significant because many bilateral investment treaties (BITs) have been concluded between individual CARIFORUM states and the major European capital-exporting states, acting individually. The Agreement is therefore a subsequent agreement to these existing BITs between states that are also parties to the Agreement. Further, the Agreement expressly preserves the rights of investors under existing or future investment treaties between CARIFORUM states and EC states. ${ }^{3}$ Thus, the Agreement expands upon, and does not limit, the restraints and liabilities that existing BITs place on the CARIFORUM states in the regulation of European investors. These aspects are critical to understanding the cumulative impact of the market access commitments undertaken in the Agreement.

\section{Substantive commitments}

The substantive focus of the Agreement's investment provisions is market access and preestablishment investment liberalization. The Agreement thus requires the Parties to remove restrictions on foreign ownership and control of their economy in sectors where they undertake positive commitments to liberalize. ${ }^{4}$

In particular, the Parties undertake market access commitments in investment (ie 'nonservice') sectors, as defined by the International Standard Industrial Classification of all Economic Activities (ISIC Rev. 3.1). Commitments are made in these sectors: Agriculture, hunting and forestry; Fishing; Mining and quarrying; and Manufacturing; and in the subsector of Production, transmission and distribution on own account of electricity, gas, steam and hot water [see Appendix B]. In turn, all sub-sectors within these sectors are liberalized, barring a specific reservation taken by the state in question. In addition, the Agreement contains extensive market access concessions in sectors that are styled as 'services' under the ISIC methodology, but that would also qualify as investment under the broad definitions of that concept in BITs which, unlike the CARIFORUM Agreement, restrict postestablishment regulation of foreign investors by the CARIFORUM states.

In the liberalized sectors, a variety of instruments that are commonly used to limit or screen foreign investment, with a view to enhancing its benefits for the local, national, or regional economy, are prohibited. These include the imposition of various restrictions or conditions on foreign investment, including limits on the number or share of foreign firms in a sector, limits on the proportion of a firm or industry that is foreign-owned, the use of an economic needs test to approve proposed investments, or requirements to engage in joint ventures with local firms. ${ }^{5}$

2 Part VI, Article 1.

3 Part II, Title II, Article 10.

${ }^{4}$ Part II, Title II, Article 6(1); Schedule of Commitments on Investment (Commercial Presence) of CARIFORUM States in Non-Service Sectors.

5 Part II, Title II, Article 6(2). The restrictions reflect the language on market access in the General Agreement on Trade in Services, Article XVI(1). 
Further, in the liberalized sectors, the Agreement establishes a general obligation of national treatment for foreign investments and investors, relative to their domestic counterparts. ${ }^{6}$ The Parties may not treat domestic firms in a way that alters the conditions of competition in their favour relative to foreign firms. (Note that the Agreement does not prohibit states from treating foreign investors more favourably than their domestic counterparts.) The obligation thus likely precludes states from applying performance requirements (other than through subsidies ${ }^{7}$ ) to foreign investors as a condition of their commercial presence, including for example requirements to employ local personnel, use local materials, produce for export, or otherwise establish linkages with the local economy or protect domestic enterprises.

Complementing these restrictions on the regulation of foreign capital is a more specific obligation not to apply capital controls to direct investments or otherwise restrict the repatriation of capital or profit from those investments. ${ }^{8}$ This operates to liberalize the capital account of the balance of payment, going well beyond normal IMF obligations to liberalize current transactions. Notably, the commitment is not subject to the Agreement's balance of payments safeguards that otherwise apply in the event of a monetary crisis.

A further commitment deals with most-favoured-nation (MFN) treatment. ${ }^{10}$ It requires the Parties to make available any more favourable treatment to which they agree, in a future economic integration agreement with a major trading economy, to investments and investors covered by the CARIFORUM Agreement. ${ }^{11}$ The commitment acts primarily as a hedge for the EC states against the possibility that CARIFORUM states might grant more generous market access to other major economies. However, it could be read expansively in order to incorporate into the Agreement a host of substantive and procedural obligations from other investment treaties, including post-establishment protections (eg duties to compensate foreign investors for 'regulatory expropriation' or 'unfair treatment') and access to investorstate arbitration. This expansive approach to the concept of MFN treatment is surprisingly common in arbitration awards to date.

Interestingly, the Agreement requires both home states and host states for investors to adopt legislation on anti-bribery, labour standards, and international environmental and labour obligations. ${ }^{12}$ It also lays out provisions and a consultation mechanism aimed at checking inter-state regulatory competition to attract investment. ${ }^{13}$

6 Part II, Title III, Article 7. Again, this reflects the GATS language, Article XVII.

7 Part II, Title II, Article 1(3).

8 Part II, Title III, Article 2(1).

${ }_{9}^{9}$ Part II, Title III, Articles 1 to 3.

10 Part II, Title II, Article 9.

11 A 'major trading economy' is any industrialized country, or any country accounting for more than one percent of world merchandise exports, or any group of countries accounting for more than 1.5 percent of world merchandise exports. Thus, a large developing states or significant grouping developing states would fall within the category.

12 Part II, Title II, Article 11.

13 Part II, Title II, Article 11; Part II, Title IV, ch 4 and 5. 
Finally, the Agreement provides for future negotiations, within fives years of its entry into force, toward further investment liberalization. ${ }^{14}$

\section{Coverage}

The Parties agree to liberalize capital flows relating to direct investment by opening their economies to foreign investors that are based in another state party and that engage in economy activity in the host state by setting up a commercial presence in its territory.

'Investor' includes both natural persons and juridical persons. The inclusion of juridical person raises the prospect of forum-shopping by EC-based investors. For instance, an ECbased investor that gains market access to Barbados as a result of the Agreement could channel the legal ownership of its Barbadian assets through Canada by establishing a shell company in Canada, in order to gain access to the additional post-establishment protections (including access to investor-state arbitration) that are available under the Canada-Barbados bilateral investment treaty. ${ }^{15}$

'Commercial presence' (ie investment) is not limited to economic activity that delivers a benefit to the development of the host state. However, the concept is apparently limited to direct investment (aimed at managerial control) rather than portfolio investment (not aimed at managerial control), given the requirements that a commercial presence - where made by constituting or acquiring a local entity - must be "with a view to establishing or maintaining lasting economic links', and given that loans extended by foreign investors must be at least five years in duration. ${ }^{16}$

The Agreement applies broadly to regulatory activity of the state. First, it applies to any measure that affects the commercial presence of an investor, except for a limited range of measures that are expressly excluded. ${ }^{17}$ Second, it defines 'measure' broadly to include acts of any branch of the state (including the legislative and judicial branches) and of any level of government. ${ }^{18}$

\section{Dispute settlement}

The Agreement is unlike other investment treaties in that it does not include an investorstate mechanism that would allow investors to bring claims directly against states for alleged violations of the treaty, leading to an internationally-enforceable damages award against the

14 Part II, Title II, Article 3.

15 Part II, Title II, Article 2. The prevalence of forum-shopping in international business means that the liabilities of host states under BITs are not limited to possible disputes arising from assets owned by investors based in the other state party to a BIT, but may extend to disputes arising from the regulation assets of investors based in third states who have channelled their investments in order to gain access to an investment treaty.

16 Part II, Title II, Article 4(a)(i) note.

17 Part II, Title II, Article 5 (excluding measures relating to nuclear materials, war materials, audio-visual services, national maritime cabotage, and certain air transport services).

18 Part II, Title II, Article 2. The definition also extends to non-governmental bodies exercising delegated public powers. 
state. Instead, dispute settlement is limited to state-state arbitration. Thus, the Agreement does not directly import the most troubling component of existing investment treaties: their use of private arbitration rather than a court (whether domestic or international) to resolve regulatory disputes between business and the state, and to delineate the policy space that is available to host governments. This is a positive aspect of the Agreement. Other positive aspects are that the Agreement assigns appointing authority to a public entity (the chairperson of the Trade and Development Committee), directs that appointments be made from a designated list of arbitrators, adopts a presumption of openness in arbitration proceedings, allows for amicus curiae briefs, and contemplates a Code of Conduct for arbitrators. ${ }^{19}$

On the other hand, the dispute settlement mechanism has important flaws. First, it allows the rulings of arbitrators to be withheld from public disclosure at the discretion of the Trade and Development Committee. Second, it limits the expertise of arbitrators to 'law and international trade'. ${ }^{20}$ Third, it precludes the publication of dissenting opinions by arbitrators. ${ }^{21}$ Fourth, in terms of its interpretation, the Agreement contains purposive statements that permit arbitrators to adopt an interpretive presumption in favour of investors, to the detriment of the regulatory position of host states. ${ }^{22}$

Most problematic, however, are two potential areas of interaction between the Agreement and investor-state mechanisms in BITs. The first is that the CARIFORUM states will be exposed to claims against them by European investors whose investments are possible only because of the market access that is granted under the Agreement. These claims are most likely under BITs between a CARIFORUM state and an EC state, although they are possible under any BIT that allows forum-shopping. Also, for purposes of post-establishment protection, BITs define investment in ways that would include assets owned in 'service' sectors of ISIC as well as 'non-service' sectors.

Second, the CARIFORUM Agreement's exclusive use of state-state arbitration is subject to the proviso that arbitrators appointed under a BIT may rely on an MFN clause in the BIT to import CARIFORUM commitments on market access into the BIT arbitration.

19 Part III, Articles 6(3), 15(2), 16, and 20.

20 Part III, Articles 19(1), 19(2), and 20(3). This expertise requirement can be varied only where both Parties agree to do so after a dispute has arisen, by appointing individuals who have 'sector expertise in specific matters'.

21 Part III, Article 19(1).

22 eg Part I, Article 1(b) and (e). eg the Agreement includes among its objectives those of 'implementing an effective, predictable and transparent regulatory framework for trade and investment' and 'supporting the conditions for increasing investment', but does not qualify these objectives with language to recognize the role of government in encouraging benefits and limiting costs of foreign investment. 


\section{Implications for development and regional integration in the ACP}

\section{Implications of the CARIFORUM Agreement}

The CARIFORUM Agreement points to three assumptions underlying the EPA model. The first is that the conclusion of EPAs is necessary to attract foreign investment into ACP states. The second and third are that this investment will further the development and regional integration, respectively, of ACP states. I shall comment on each in turn and then conclude by commenting on the asymmetric character of ACP states' concessions under an EPA.

First, one must ask whether ACP states really need to use international law to attract foreign investment by constraining their governments at the domestic level. If investment is foreclosed by domestic measures, then states can open their economies by changing their own laws and policies. Also, if we accept that investment can have both positive and adverse impacts on a host economy and that government has a role to play in managing these impacts, it is arguably much more appropriate to amend domestic law so as to authorize governments to negotiate and approve proposed investments that are judged beneficial for the local economy on a case-by-case basis, rather than to adopt blanket commitments covering entire sectors at the international level. ${ }^{23}$

Moreover, the evidence is weak at best that existing investment treaties actually draw in foreign investment, and there is no evidence that they are more effective in this respect than investment contracts. ${ }^{24}$ Without such evidence, it is inadvisable for states to relinquish their regulatory flexibility and policy space in a wide range of fields, in exchange for an elusive promise of beneficial investment that could in all likelihood be secured by other means.

Thus, by sidelining domestic tools to encourage foreign investment, the EPA model displaces the adaptability that domestic instruments offer in terms of the tailoring and staging of regulation as the costs and benefits of market access in different sectors become more apparent over time. It is in this sense that the EPA model demands that ACP states relinquish core policy space; they must accept legal restrictions in a treaty instrument that lacks adaptability and that will be very difficult to adjust or withdraw from.

A second assumption is that foreign investment made possible by liberalization will further the development of ACP states. But the EPA model does not account for the potentially adverse impacts of foreign investment for development or acknowledge the important role

23 The EC could play a constructive role in this respect by providing financial and other support for the development of domestic capacity to evaluate and approve specific investments.

24 eg M. Hallward-Driemeier, 'Do Bilateral Investment Treaties Attract Foreign Direct Investment? Only a Bit... and They Could Bite' (World Bank Policy Research Working Paper No. 3121, Washington, June 2003) 4-5 and 22-3; P. Egger and M. Pfaffermayer, 'The Impact of Bilateral Investment Treaties on Foreign Direct Investment' (2004) 32 Journal of Comparative Economics 788; J. Tobin and S. Rose-Ackerman, 'Foreign Direct Investment and the Business Environment in Developing Countries: the Impact of Bilateral Investment Treaties' (Working paper, Yale University, 3 January 2005). 
of government in preventing and limiting these impacts. In doing so, it unduly restrains the policy space of host states. They are foreclosed from adopting a selective approach to the admission of foreign investors, from negotiating conditions on foreign investment that would encourage linkages with the host economy and protect local producers, and from emphasizing South-South integration based on privileged market access. Further, in any sector where an EC investor comes to own substantial assets in an ACP economy, major liabilities will follow automatically under existing investment treaties that impose extensive post-establishment constraints on the regulation of foreign investors.

In this respect, the CARIFORUM Agreement acknowledges that states have a right to regulate, but then expressly subjects that right to the Parties' commitments on investment liberalization ${ }^{25}$ and to the post-establishment protections that newly admitted investors will enjoy under BITs. Thus, the EPA model requires states to relinquish their customary right to govern entry by foreign capital into their economies and to regulate foreign capital once it is established. This is authority has been used successfully by many states, especially in Asia and among the major capital-exporters, to develop competitive industries and national centres of capital before opening their economies to foreign ownership. It is also used widely by all states to enact regulatory measures that apply generally to investors, for a wide range of development purposes, and that will be fraught with risks and liabilities under BITs, once an EPA leads to expanded foreign ownership of the economy (see below).

The second assumption is that foreign investment made possible by liberalization will further the development and regional integration of ACP states. ${ }^{26}$ This assumption appears naive, not to say disingenuous, in important respects. For example, in terms of regional integration, the Agreement states that 'the provision of appropriate regulatory frameworks for trade in services and investment' (including market access) 'will contribute to the deepening of [the Parties'] regional integration process and the realization of the objectives of this Agreement'. ${ }^{27}$ This statement equates regional integration within the Caribbean region to regional integration between the Caribbean region and Europe. But the latter conflicts overtly with the former. Allowing market access by European firms that are based in larger European markets will spoil many opportunities for economies of scale to develop among Caribbean enterprises based in the Caribbean market.

In resolving this conflict, what does the Agreement do? It expressly subordinates regional investment to investment liberalization. ${ }^{28}$

25 Part II, Title II, Article 1(4) (clarifying that the 'right to regulate and to introduce new regulations to meet legitimate policy objectives' is retained, but only 'consistent with the provisions of this Title').

${ }^{26}$ eg Part I, Article 8 (stating that 'development co-operation' shall focus on various areas including 'the diversification of CARIFORUM exports of goods and services through new investment and the development of new sectors', without recognizing that foreign investment may also crowd out domestic enterprises and substitute foreign for local suppliers).

${ }^{27}$ Part II, Title II, Article 3 ter.

28 Part I, Article 4(4) (stating that 'the pace and content of regional integration is a matter to be determined exclusively by the CARIFORUM States in the exercise of their sovereignty and given their current and future political ambitions' but that this is 'without prejudice to the commitments under in this Agreement'). 
Finally, it is important to highlight that the EPA model is asymmetric in that ACP states assume much greater liabilities in relation to investment than do the EC states because ACP states are overwhelmingly a destination for direct investment from the EC rather than a source of direct investment into the EC. The significance of this asymmetry is heightened further by the extent to which the Agreement delivers privileged market access to European investors, relative to other capital-exporting regions. Commitments by EC states under the Agreement should reflect the groundbreaking nature of this concession.

\section{Implications of the Agreement's interaction with BITS}

One of the most important features of the EPA model, in light of the CARIFORUM Agreement, is its expansion of the liabilities that ACP states face under other investment treaties, especially their bilateral investment treaties with EC states [see Appendix C].

Existing BITs concluded by EC states do not contain commitments on market access but are instead limited to post-establishment protections for investors. They differ, as such, from the investment treaties of other major states, which typically include commitments on both pre-establishment and post-establishment stages of investment. ${ }^{29}$ In this respect, the market access commitments in EPAs are meant to 'fill a gap' in the BIT programmes of European capital-exporters by opening host economies to European investment in the manner of a US regional or bilateral investment treaty. However, once markets are opened by an EPA, the post-establishment protections available to European investors in European BITs will be triggered.

This aspect of market access under EPAs is important because BITs, unlike the CARIFORUM Agreement, allow investor-state arbitration and thus expose host states to major liabilities arising from the prospect of direct claims by investors and internationallyenforceable damages awards against the state. Under a BIT, any state measure, whether or not it is permitted under an EPA, may lead to a claim and a damages award under a BIT.

The development implications of this are vitally important. Investor-state arbitration is a uniquely powerful means to discipline host states because (a) it allows direct claims by investors, typically without a requirement to pursue legal remedies in the host state, (b) it allows for damages awards for any regulatory act of the state, including legislation, and (c) it relies on private arbitration to resolve disputes in a way that is structurally biased against host states. To date, there have been well over 100 claims against developing countries under BITs, leading to dozens of damages awards. Numerous states have been ordered to pay awards worth tens or hundreds of millions of dollars. In many cases, awards arise from general regulatory measures that affect foreign investors indirectly and in unanticipated ways. As such, exposure to investor-state arbitration may impact, not only the fiscal position of a government, but also its ability to plan and cost out development policies that have the potential to affect the economic position of a foreign investor.

${ }^{29}$ eg regional agreements like CAFTA, bilateral trade agreements, and US BITs. 
Judging from the experience of other states targeted by investor claims under BITs, the liabilities arising from investor-state arbitration are especially prevalent in the energy and resources sectors and in sectors where state assets have been privatized. ${ }^{30}$ In these sectors, countries targeted for claims have included Argentina, Bolivia, Bulgaria, Ecuador, Canada, the Czech Republic, Egypt, Lebanon, Pakistan, Peru, South Africa, and Tanzania, for example. ${ }^{31}$ Most prominently, Argentina has faced dozens of investor claims arising from measures to address the country's financial crisis in 2001, and it has lost all six claims that have reached the stage of a final award, leading to orders against Argentina to pay over $\$ 800$ million in total to European and US firms.

Importantly, the general exceptions ${ }^{32}$ and other useful language ${ }^{33}$ in the CARIFORUM Agreement that emphasize objectives of sustainable development, food security, social benefits, labour standards, and safeguards for the balance of payments, will be of little use to the host state in an investor-state arbitration under a BIT. A BIT dispute, though it relates to an investment made possible by an EPA, will be resolved with reference to the terms and purposes of the BIT, and the great majority of BITs omit the general exceptions and useful language found in the CARIFORUM Agreement. Thus, once an investor is admitted to a state's territory, any post-establishment regulation by the state that implicates a BIT (to which the investor has access) will not be protected by EPA exceptions on human health, resource conservation, direct taxation, and so on.

In these respect, the CARIFORUM Agreement has direct and indirect impacts on development and regional integration. Its direct impacts arise from the problematic assumptions that a treaty is required to encourage foreign investment, and that European investment will, as a rule, deliver benefits to host states in spite of the much reduced policy space of host governments. Its indirect impacts arise from the Agreement's interaction with other investment treaties that provide post-establishment protections for foreign investors, including access to investor-state arbitration. In light of this interaction, different states will be affected in different ways by an EPA depending on the degree to which (a) the state might otherwise use its domestic authority to limit costs and enhance benefits of investment, (b) additional investors enter the state's economy as a result of an EPA, and (c) these investors have access to post-establishment protections under other treaties.

${ }^{30}$ In this respect, the Agreement does not mandate, but also does not preclude, the privatization and foreign ownership of public assets: Part II, Title II, Article 1(2); Schedule of Commitments on Investment (Commercial Presence) of CARIFORUM States in Non-Service Sectors. Indeed, the language of the Agreement suggests that privatization is an anticipated outcome of market access.

31 The author was informed in 2005 by a legal advisor to the president of a large developing country that the cost of defending a single claim had consumed roughly half of the entire annual budget of the country's department of justice.

32 Part IV, Article 1(1).

33 eg Part I, Article 2 ('The Parties understand this objective to apply in the case of the present Economic Partnership Agreement as a commitment that: a) the application of this Agreement shall fully take into account the human, cultural, economic, social, health and environmental best interests of their respective population and of future generations...'). 


\section{Implications of subsequent negotiations at a multilateral and bilateral level}

The CARIFORUM Agreement reflects an EPA model that imposes extensive restraints on the regulatory flexibility of ACP countries to decide whether to admit foreign investors and under what conditions, and thus limits the policy space that is available to host governments to manage costs and benefits of investment in light of their own development and regional integration priorities. In turn, by opening the door to much greater foreign ownership of their economies, the EPA model expands the liabilities of ACP countries under other treaties. States should therefore weigh the perceived benefits of an EPA against these significant costs and liabilities.

To date, other agreements concluded by ACP states with the European Union are preliminary agreements that establish an initial framework for a full EPA. They do not contain investment provisions as in the case of the CARIFORUM Agreement, although they do contain a similar dispute settlement process. Also, most of these preliminary agreements contemplate near-term investment liberalization by requiring the Parties, eg, to 'cooperate to facilitate all the necessary measures leading to the conclusion' of a global EPA 'as soon as possible' and 'before the end of 2008', including provisions on 'investments'. ${ }^{34}$

Recommendations for these negotiations are discussed below.

At the multilateral level, the CARIFORUM Agreement and other EPAs have the potential to undermine the will of ACP and other capital-importers to resist political pressures to make concessions on investment. This is particularly true in the case of states that have not otherwise conceded significant market access commitments in BITs or other treaties. In itself, the proliferation of bilateral investment treaties since the 1990s reveals the dangers posed by the inter-state competition among developing countries, encouraged by capitalexporting states, to concede ever-higher obligations to admit and protect foreign investors. This poses an ongoing challenge to the groupings of capital-importers that have successfully opposed concessions on investment in multilateral forums, including the WTO. Notably, the CARIFORUM states, relative to other capital-importing regions, have not concluded many investment treaties that contain market access commitments. ${ }^{35}$

Thus, the more ACP states accept intrusive constraints in EPAs and other investment treaties, the higher the bar rises as to what qualifies as a hospitable investment climate, and the less each state can derive an advantage by conceding more to foreign investors than its 'competitors' among other developing countries. By maintaining a unified position, on the other hand, ACP states enhance the bargaining position of capital-importers as a group, and the corresponding ability of individual states to target selectively their legal concessions to investors via investment contracts.

\footnotetext{
${ }^{34}$ eg Agreement Establishing a Stepping Stone Economic Partnership Agreement Between Ghana, on the One Part, and the European Community and its Member States, on the Other Part, Article 44.

35 As at June 2006, the Dominican Republic, Grenada, Jamaica, and Trinidad and Tobago had done so with the United States, and Barbados and Trinidad and Tobago had done so with Canada.
} 


\section{Recommendations for review or amendment of the EU- CARIFORUM Agreement}

The following is recommended for review or amendment before signature or ratification of the Agreement.

The Agreement's statement of objectives in favour of investment ${ }^{36}$ should include additional language that recognizes states' right to regulate. Such language might draw, for example, on the Agreement's definition of sustainable development, ${ }^{37}$ by affirming the Agreement's investment-related objectives 'while respecting the right of the Parties and of the Signatory CARIFORUM States to regulate investors in order to advance the human, cultural, economic, social, health and environmental best interests of their respective population and of future generations'.

The Agreement's definition of the right to regulate should be strengthened. ${ }^{38}$ It should track the more robust language used to protect the right to regulate in relation to the Parties' commitment not to engage in regulatory competition in order to attract investment. ${ }^{39}$

The Agreement should clarify that any commitment to MFN treatment is limited to the preestablishment phase of an investment and that it does not extend to post-establishment protections or to procedural mechanisms that are available to investors under other economic integration agreements.

The Agreement's commitment to liberalize the capital account of the balance of payments ${ }^{40}$ should be subject to the balance of payments safeguard. ${ }^{41}$ Further, based on Argentina's experience in investor-state arbitration, the Agreement's exception for security measures should include temporary measures necessary to address a monetary crisis. ${ }^{42}$

The Agreement's exclusion of a commitment to privatize public undertakings should be strengthened. ${ }^{43}$ Drawing on other exclusions in the same Article, it should read: 'This Title shall not apply to measures affecting public undertakings or limiting the privatisation of public undertakings'. Further, the Agreement should preclude the application of postestablishment protections in other investment treaties to foreign investments in sectors that are privatized following the conclusion of the CARIFORUM Agreement. The Agreement

\footnotetext{
36 Part I, Article 1.

37 Part I, Article 2(a).

38 Part II, Title II, Article 1(4). laws and policies').

40 Part II, Title III, Article 2(1).

${ }^{41}$ Part II, Title III, Article 3.

42 Part IV, Article 2.

${ }^{43}$ Part II, Title II, Article 1(2).
}

39 Part II, Title IV, ch 4, Article 2 (affirming the right of states to regulate 'in order to achieve their own level of domestic environmental and public health protection and their own sustainable development priorities, and to adopt or modify accordingly their environmental laws and policies' and 'in order to establish their own social regulations and labour standards in line with their own social development priorities, and to adopt or modify accordingly its relevant 
should also contain a general exception for measures relating to the alleviation of poverty or assurance of universal access to basic services.

The Agreement should list additional areas of expertise, such as international law or human development, as suitable qualifications for arbitrators on the designated list. ${ }^{44}$ Also, as an accountability check, the discretion of the Trade and Development Committee to not publish an arbitration ruling ${ }^{45}$ should be limited to specific and legitimate grounds for confidentiality. Likewise, the Agreement should permit the publication of dissenting opinions by arbitrators.

The Agreement precludes the arbitration of WTO disputes under the CARIFORUM dispute settlement process. It also precludes concurrent arbitration of the same dispute under WTO and CARIFORUM dispute settlement. ${ }^{46}$ However, the Agreement should include similar language precluding the arbitration (whether investor-state or state-state) of CARIFORUM disputes under other investment treaties concluded between states that are parties to the CARIFORUM Agreement. In particular, it should preclude the arbitration under those treaties of disputes concerning the rights and obligations of the Parties to the Agreement, or of disputes that are the subject to dispute settlement under the Agreement.

The CARIFORUM Agreement provides an excellent opportunity to address flaws in investor-state arbitration under existing BITs between states that are parties to the Agreement. These might include, for instance, provisions to designate a list of approved arbitrators, to ensure openness in proceedings, to allow amicus curiae briefs, and to apply a Code of Conduct to arbitrators. Further, appointing authority for arbitrators appointed under BITs should be assigned to a public body in which voting power was allocated more equitably between capital-importing and capital-exporting interests. Alternatively, the Agreement could provide that investor claims arising under an existing BIT between an EC state and a CARIFORUM state are to be referred to the CARIFORUM dispute settlement process instead of BIT arbitration. Ideally, the Agreement would establish a standing dispute settlement body or international court, staffed by tenured judges, to resolve investment disputes under the Agreement and BITs. These are all feasible options, in legal terms, because the EC states that have concluded BITs with CARIFORUM states are also parties to the CARIFORUM Agreement.

To prevent forum-shopping by non-European investors, the Agreement should expressly foreclose, in relation to any investment covered by the Agreement, access by the respective investor to dispute settlement under other investment treaties where the investor would not qualify for coverage under the Agreement.

44 Part III, Article 20(2).

45 Part III, Article 19(1).

46 Part III, Article 21(1). 


\section{Recommendations for other ACP regions}

Other ACP states embarking on negotiations with the EU need to ensure they have assessed the degree to which the costs of the increased foreign investment and ownership that is enabled by an EPA - including the costs of imposing treaty restrictions on measures aimed at development or regional integration, and the liabilities to claims under the EPA and other investment treaties - are clearly outweighed by benefits of increased investment or by other benefits of the EPA.

In the course of this assessment, ACP states should determine existing and projected domains of foreign ownership within the economy so as to identify those in which the amount of foreign investment at stake has the potential to trigger disputes with a foreign investor or its home state. This should include an assessment of the degree to which market access commitments in an EPA will expand foreign investment and the corresponding liabilities of the state to arbitration claims.

Thus, ACP states should consider their position not only in terms of costs and benefits of their commitments to market access in sectors covered by an EPA, but also in terms of their post-establishment commitments under other investment treaties. They may also wish to link EPA negotiations to the renegotiation of existing investment treaties in order to limit their liabilities arising from forum-shopping, undue restrictions on the right to regulate at the post-establishment stage, and the structural bias against capital-importing states in investorstate arbitration.

ACP states should also avoid strictly any further commitments to investor-state arbitration in an EPA or any other treaty. They should limit future consents to investor-state arbitration to consents in investment contracts that are concluded in anticipation of a specific project whose benefits are judged clearly to outweigh the significant exposure that consent to investor-state arbitration entails.

ACP states should set aside a contingency fund for legal costs and awards arising from possible disputes concerning their commitments in any EPA and in other investment treaties. ACP states should also develop an in-house capacity for the litigation of claims arising from investment disputes.

ACP states should consider the more specific recommendations in the previous section. 